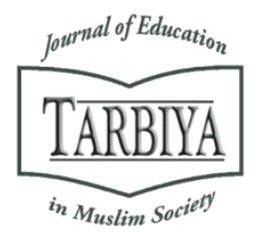

Available online at TARBIYA: Journal of Education in Muslim Society Website:

http://journal.uinjkt.ac.id/index.php/tarbiya

TARBIYA: Journal of Education in Muslim Society, 2(2), 2015, 191-203

\title{
CURRICULUM READINESS AND PROGRAM EVALUATION IN IMPLEMENTING INDONESIAN NATIONAL QUALIFICATIONS FRAMEWORK CURRICULUM (KKNI)
}

\author{
Fauzan, Asep Ediana Latip \\ Syarif Hidayatullah State Islamic University of Jakarta, Indonesia \\ E-mail:fauzan@uinjkt.ac.id
}

Received: $05^{\text {th }}$ September 2015; Revised: $21^{\text {th }}$ October 2015; Accepted: $27^{\text {th }}$ December 2015

\section{Abstract}

The purpose of this study is to determine the study program readiness in State Islamic University (UIN) Jakarta in implementing KKNI based curriculum. It can be seen from the availability of the documents course curriculum in UIN Jakarta which consists of $71 \%$ of the vision, mission, graduate profile, achievement of learning, the curriculum structure and Semester Lesson Plan (RPS). It also can be evidenced by the quality of the documents that 1) $99 \%$ of study programs have developed a vision and mission for the implementation of the curriculum. 2) $77 \%$ of study programs have developed a graduate profile according to level 6 of the KKNI based curriculum which is the basis for the development of graduate-level profile. 3) development of learning achievements in environmental studies program UIN Jakarta, $59 \%$ of the study programs have been formulated learning achievements which is in accordance with the learning outcomes defined for an undergraduate level. 4) $35 \%$ of the curriculum structure of the study program have met KKNI implementation standards. 5) development of Semester Lesson Plan (RPS) program in environmental studies UIN Jakarta, $82 \%$ of the Semester Lesson Plan or RPS which is in line with the principles of RPS development expected in the KKNI implementation has been developed by several study programs at UIN Jakarta.

Keywords: readliness of the major; implementation of KKNI

\section{Abstrak}

Penelitian ini bertujuan untuk mengetahui kesiapan program studi di Universitas Islam Negeri (UIN) Syarif Hidayatullah Jakarta dalam mengimplementasikan Kurikulum berbasis KKNI. Kesiapan tersebut dapat dilihat melalui ketersediaan dokumen kurikulum program studi di UIN Jakarta yang terdiri dari $71 \%$ visi, misi, profil lulusan, capaian pembelajaran, Struktur Kurikulum dan Rencana Pembelajaran Semester (RPS). Selain itu, kesiapan program studi dalam mengaplikasikan dapat dibuktikan dari kualitas dokumen, yakni 1) 99\% program studi telah mengembangkan visi dan misi untuk pelaksanaan kurikulum. 2)77\% program studi telah mengambangkan profil lulusan menurut level 6 Kurikulum berbasis KKNI yang merupakan dasar untuk pengembangan profil lulusan. 3) pengembangan capaian pembelajaran di lingkungan program studi UIN Jakarta, 59\% program studi telah merumuskan capaian pembelajaran yang sesuai dengan hasil belajar yang ditetapkan untuk program sarjana. 4) 35\% struktur kurikulum program studi telah memenuhi standar pelaksanaan KKNI. 5) pengembangan Rencana Pembelajaran Semester (RPS) program studi di lingkungan UIN Jakarta, 82\% dari Rencana Pembelajaran Semester atau RPS yang sejalan dengan prinsip-prinsip pengembangan RPS yang diharapkan dalam pelaksanaan KKNI telah dikembangkan oleh beberapa program studi di UIN Jakarta.

Kata kunci: kesiapan jurusan; pelaksanaan KKNI

How to Cite : Fauzan., Latip A., E. (2015). Curriculum Readiness and Program Evaluation in Implementing Indonesian National Qualifications Framework Curriculum (KKNI).TARBIYA: Journal Of Education In Muslim Society,2(2), 191-203. doi:10.15408/tjems.v2i2.3179.

Permalink/DOI:http://dx.doi.org/10.15408/tjems.v2i2.3179 


\section{Introduction}

The era of globalization, along with technological advances and rapid business, demands the great ability of the human mind (brain power). The role of higher education in the era of globalization, in international and regional cooperation is very strategic. College graduates competition are no longer local or national, but already takes place in global and international. The demands of the international community towards college graduates, requires the improvement of the quality of the higher education system, ranging from the recruitment system, the learning process, a means of pre facilities, management, up to the educational curriculum. It is a necessity if the curriculum continues to present the patterns of change as a result of the development of the people's minds.

According to Syaodih (2011), the response to changes in the curriculum can be seen from various rules of law which cover the implementation of the new curriculum. For example, the birth of the Act No. 14 of 2005 on Teachers and Lecturers; Law No. 12 of 2012 on Higher Education; Presidential Decree No. 8 of 2012 on Indonesian National Qualifications Framework (read: KKNI); and the Regulation of the Minister of Education and Culture No. 49 of 2014 on the National Standards of Higher Education. The policy implications did not directly give impact on the pattern of changes in the curriculum of each study program even for most cases in the adjustment of teaching materials (content) that will be delivered to students. Kaber (1998).

KKNI itself is a frame of reference, the minimum standard that could be used, the recognition of gradual education which is done or understood as well as the qualification frameworks competence in the field of education and in the field of vocational training and work experience in order to award the recognition of the competence of work that are in accordance with the jobs structure in various sectors. KKNI is the embodiment of quality and identity of Indonesia related to national education and training system that is owned by Indonesia. (Presidential Decree No. 8 of 2012)

In KKNI perspective, every study program is required to clarify the "profile of graduates' expected through tracer studies, feasibility studies and analysis study of the needs of the community. Profile of graduates reflects the minimal ability that should be mastered by students after graduation that refers to the four aspects of the requirements (1) attitude (attitudes), (2) field of workability, (3) knowledge, and (4) managerial and responsibility. The fourth capabilities must then be translated into a performance and learning (learning outcomes) for each subject in the study program. Thus, all the planning for learning or Semester Implementation Plan (RPS) should be based on learning outcomes (Learning Outcome) that fit the needs of the graduate profile.

\section{KKNI based Curriculum}

\section{The Background of KKNI}

To develop equal quality and similar understanding of various occupations and professions qualifications in this global era, an international parameter qualification of education graduate in Indonesia is definitely required. Beside this reason, internally, the quality of education in Indonesia, especially higher education has a very high disparity. There is no equal qualifications among $S 1$ graduate study programs, even for graduates from the same study program produced by different universities. In addition, there are also some differences among the graduates of the academic type of education, with vocational and professional. As a result, this educational qualifications tangle has unfortunately decreased 
the academic accountability of higher education institutions.

Through Indonesian Presidential Regulation Number 8 Year 2012 on the Indonesian National Qualifications Framework, encouragement as well as support for developing similar qualification in education in Indonesia has been given in the form of a framework of qualifications. This qualification became a milestone for the world of higher education in Indonesia to produce qualified human resources who can compete on a global level. Indonesian Presidential Regulation No. 8 of 2012 on article 1 states that:

Indonesian National Qualifications Framework, hereinafter referred KKNI, is the framework that leveling the competence qualification which integrate education and job training and work experience in order to award the work competencies which are in accordance with the people's working ability in various sectors.

KKNI also been prepared in response to ratification by Indonesian government on December 16, 1983 and updated on January 30, 2008 to the Convention of UNESCO on the recognition of education diplomas and higher degrees education (The International Convention on the Recognition of Studies, Diplomas and Degrees in Higher Education in Asia and the Pacific). In this case, the presence of KKNI is hoped to be used as a guide for foreign employers when they have an intention to employ Indonesian workers

\section{Profile of graduates and Learning Outcome}

$\mathrm{KKNI}$ is gradual competence and qualifications framework to reconcile, equalize, and integrate the fields of education and job training and work experience in order to award the work in accordance with the recognition of the competence structure of employment in various sectors. KKNI is the embodiment of quality and identity of the Indonesian nation associated with national education and training system that is owned by Indonesia.

Of the nine levels of KKNI, there are three categories that can be identified, namely 1) the operator (junior level up to D1), 2) the analyst (D2-S1), and 3) the Expert (professional education, S2, and S3). Based on the Mandate of the Ministry of Education No. 16 year 2007 on Qualifications and Competency Standards, Madrasah Ibtidaiyah Teacher Education Program (PGMI) as a study program is having the authority to prepare prospective Elementary teachers in grade 6 level position, the analyst level.

To reach the "analyst level", every study program should begin determining the expected Graduate Profile. This expected graduate profile will in turn give implications to the development of the learning outcomes which is reflected in the syllabus.

As a qualification framework, KKNI force every study program to create a national and international standard qualification. Additionally, to achieve an international standard, each study program should prepare the expected graduates profile and learning outcomes. The study program should think of the certain job suitable for their alumny when they created the expected learning outcomes. Learning outcomes must cover attitudes, knowledge, and skills.

The agreement of an association of a study program plays a very significant role in designing the profile of a study program. For example, the association of PGMI study programs recommend that PGMI university graduate is a candidate of an Elementary class teachers and some other recommended professions are: 1) a consultant of Primary Education, 2) Author , 3). Counselor, 4) Religious Supervisor, 5) 
Entrepreneurs, and 6) Researcher in the field of basic education.

Following are the description of the formulation of learning outcomes that should appear in the document of KKNI based documents of a Study Program.

\section{Steps in designing KKNI based program study Curriculum.}

Academic education, profession, or vocation for each field of study is managed by the study program. The study program should have in charge in designing, conducting and evaluating the course curriculum so that the curriculum meets the relevance and quality aspects. Hamid (2005). Aspects of relevance covers the user's needs, a deep understanding of the study programs, and the feasibility of KKNI implementation (Presidential Decree No. 8 of 2012).

In order to develop an effective curriculum, we need a sound framework, by doing several steps such as the need analysis study, a feasibility study, comparative studies and benchmarking, evaluating the curriculum being implemented, tracer study or tracking the alumni, evaluating the evaluation process, curriculum development, validation and revision, and public testing. Next, in designing the reference framework, the study program must involve the entire academic community, professional associations, alumny users, relevant expert groups, as well as other users (stakeholders). Thus, the process is carried out in accordance with the vision, mission, and objectives of the study program, the faculty, the university, and the national education goals. (Asep, 2009; Daryanto, 2005).

There are several steps in designing KKNI based study programs: First, vision and mission, goals, and objectives of a study program should get along with the vision, mission and goals of the faculty and the university. The vision and mission of a program study is the future aim of the entire academic community of a study program. The Vision of a study program is constructed based on some input from the entire academic program of study. The mission is something that must be carried or should be implemented as the elaboration of a vision that has been set within a certain time and should become a reference for the preparation of a study program. The purpose of the program study reflects the level of quality that should be achieved by each program of study.

Second, in setting up the expected learning achievements of the study program, several things that should be included are 1) general attitudes, 2) general knowledge, and 3) general skills, which are constructed based on Presidential Decree No. 8 of 2012 on the Indonesian National Qualifications Framework and Law of Indonesian Minister of Education number 49 year 2014 on Higher Education National Education Standards (SNPT) that are formulated by the association of several study programs of Higher Education.

Third, the curriculum map should come in the form of a matrix, linking the competency course (course learning outcomes) with a class. The formulation of the curriculum map refers to the Practical Guidelines for Curriculum Development.

Fourth, after the curriculum map has been formed, the next step is to determine the Structure and content of the curriculum which appears as a list of the course names and distribution of the subjects on the allocated time. Development of the structure and content of the curriculum refers to the Basic Curriculum Framework and Practical Guidelines for Curriculum Development Studies Program.

Fifth, the next step is to determine the course subjects which consist of: (1) the name of the course and the code, (2) weight, (3) the 
prerequisites, if any, (4) the course learning outcomes, (5) a description of the teaching materials which supports the achievement of competencies, (6) book sources.

Sixth, create rules regarding the burden of learning and graduation that includes an explanation of the number of credits that must be taken by students (compulsory and optional) to be passed on certain courses. Again, the setting of this case should refer to the Basic Curriculum Framework.

Seventh, Semester Lesson Plan (RPS) should be made as an outline plan that will be carried out along the semester. RPS is an integral part of the curriculum.

\section{Method}

\section{Approach and Method}

This research used two approaches (mixed method), namely quantitative and qualitative approaches. Both approaches were used in analysing the data in order to create more comprehensive and valid research result. Quantitative approach was used to process the quantitative data, while the qualitative approach was used to process the qualitative data. Quantitative data were derived from the analysis of document on the implementation of the study program at UIN Jakarta. Qualitative data, on the other hand, were derived from interviews and observation obtained by researchers. Chaedar (2011).

Considering the effectiveness and efficiency of the availability of time and cost of this research, it is directly stated that the purpose of this research is to know the readiness of several study programs at UIN Jakarta in implementing KKNI based curriculum. Moreover, 54 study programs from 11 different faculties were chosen as the subject of the research. Regarding this, Sudjana (1991)) stated that the determination of the subject of study based on the research objectives is called purposive sampling. Similar statement was also revealed by Lexi Moleong (2013). Several reasons to choose this research subjects are 1) most of the study programs have already conducted the KKNI curriculum workshop, 2) having a minimum B score for its accreditation. accreditation status is part of quality assurance which is used as a basis for determining the subject of the research objectives.

\section{Data analysis technique}

The data obtained for this study are from library study, documents study and interviews. The data were processed by using descriptive analysis techniques. Descriptive analysis is used to describe the whole process of KKNI Based Curriculum Implementation. While the quantitative data obtained will be analyzed by the quantitative form of presentation to illustrate the generalization. As a qualitative research, in reporting this research data were developed in a grounded (grounded theory) because the data were reported by describing based conceptualization, categorization, and prepositions (Moleong, 2013).

\section{Results and Discussion}

\section{The Study Program Readiness in Implementing KKNI based Curriculum}

In the implementation process, generally curriculum can be divided into two parts: 1) curriculum documents (curriculum plan), usually presents in the form of courses details, syllabus, learning design, and achievement evaluation system. 2) learning activities of an actual curriculum. This means that a curriculum change must be started from the changes of curriculum documents, then followed by the implementation of changes in teaching learning 
activities, creating a learning atmosphere, as well as how the evaluation / assessment of learning.

If the curriculum reform is focused on the curriculum documents and the learning process, this will in turn lead to a broader perspective on the curriculum. Therefore, the curriculum can act as: (1) higher education management policy to determine the direction of education; (2) a philosophy that will characterize the development of a community and academic climate; (3) a Patron or Pattern Learning; (4) an atmosphere or climate that is formed from the interaction of managerial PT in achieving learning goals; (5) as a References quality of the quality assurance process; and (6) a measurement of the success of $\mathrm{HE}$ in producing graduates that benefit society (See Handbook Development CBC, Higher Education, 2008). As a system, curriculum can be implemented optimally when each component can support each other suitability of each component related to each other like a chain that if one component is not suitable to be a mistake systemic impact on the failure of the embodiment of national ideals including failure to establish accountable and democratic society (a fragment of Law No. 20 of 2013). Curriculum component as being described by Abdullah consists of objectives, content, process, and evaluation.

In line with that theory, National Education Standards Agency (BSNP) developed the implementation of a curriculum based on the 8 national education standard as an important component of the implementation of the curriculum. These are competency standards, content standards, process standards, assessment standards, standards of facilities and infrastructure, financial standard, educators standard, and management standard. All of these eighth standards were set in terms of regulation of the ministry of education and culture as Permendikbud No. 54 of 2013 on competency standards, Permendikbud No. 64 of 2013 on the
Content Standards, Permendikbud No. 65 on the standard process, permendikbud No. 103 of 2014 of the standards process, and permendikbud no 66/104 2013/2014 year of assessment standards.

Meanwhile, KKNI based curriculum has similar implementation in its process. The KKNI based curriculum consist of the establishment of the vision and mission of the study program, the learning achievement of a study program, the graduate profile of a study program, the curriculum structure of a study program and the syllabus of the course. In addition, KKNI is the embodiment of quality and identity of the Indonesian nation associated with national education and training system that is owned by Indonesia. (Presidential Decree No. 8 of 2012)

Based on KKNI Curriculum documents, the alumny of a Higher education degree were directed at three categories, namely 1) the operator (junior level up to D1), 2) the analyst (D2-S1), and 3) Expert (professional education, S2, and S3). As the mandate of Permendikbud No. 16 of 2007 on Qualification Standards and Competency, bachelor level Study Program has the authority to prepare prospective teachers to grade 6 level position, the analyst level.

The diagram below illustrated the availability of the KKNI based curriculum documents:

Diagram 1 . The availability of KKNI based curriculum documents

Lengkap $\quad$ Kurang Lengkap

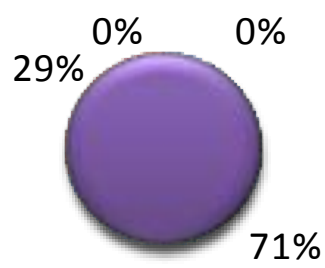


Based on the diagram above, it can be seen that $71 \%$ of the study program at UIN jakarta had a complete KKNI based curriculum documents and $29 \%$ had an incomplete KKNI based curriculum documents. In other words, 12 study program had sufficient KKNI based curriculum documents and the other 5 study programs didnot have sufficient KKNI based curriculum. Most of those 5 study program did not have teaching and learning activity planning or RPS (Rencana perkuliahan semester). Curriculum specialists, Muhaimin (2007) said that the readiness of the implementation of a curriculum can be seen from the availability of the curriculum documents. Generally, the curriculum documents was developed by the study program through the workshop held at the faculty and university level. Workshop on university level was hold to determine the peculiarities of university refers to the vision of science, Indonesian, and Islam. Workshop at faculty has also been implemented for the determination of the peculiarities of the faculty curriculum. The graphic below illustrated the document readiness KKNI based curriculum at UIN Jakarta.
Beside looking to the study program's curriculum document readiness, researchers also checking the implementation of hidden curriculum, which is one of the indication of KKNI based curriculum implementation. Muhaimin (2007). Madjid Khon, the head of the Islamic religious Education (PAI) mentioned that to develop a good student attitudes, PAI study program conducting several "habitual activities", such as reciting the Qur'an every morning, praying together (Jama'ah), and urging the lecturers to be a good model of discipline and responsibility for the students.

However, after doing more in-depth study, interviews and field notes at several study programs or departments of UIN Jakarta, it can be invered that most of the study programs have improperly implemented KKNI curriculum. This is because $90 \%$ of the study program did not involve lecturers, stakeholders and other related institutions in developing their curriculum.

Graphic 1. Readliness Documents KKNI Majorin UIN Jakartaa graph illustrating the readiness framework

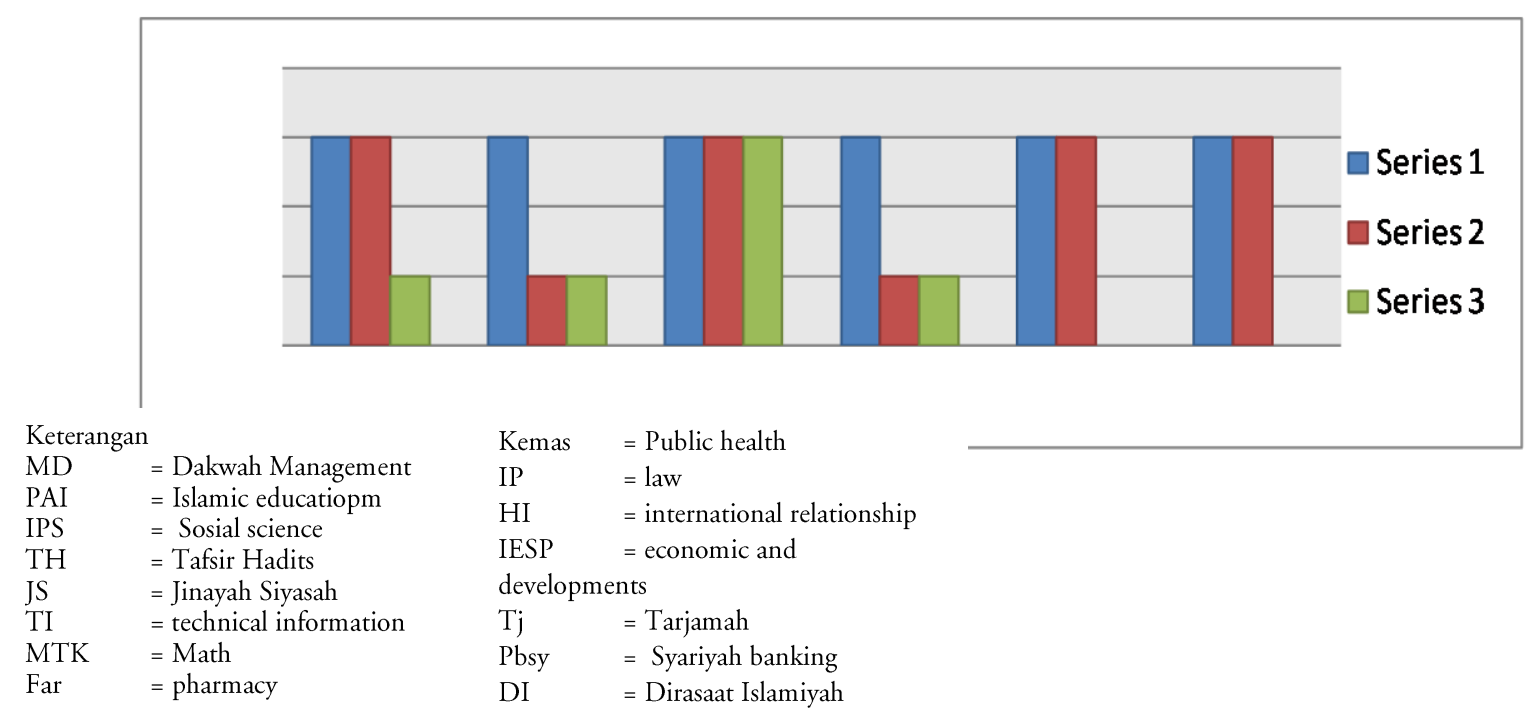

Copyright @ 2015, TARBIYA: Journal of Education in Muslim Society, P-ISSN: 2356-1416, E-ISSN: 2442-9848 | 197-203 


\section{Lecturers development program readiness}

To involve the lecturers in developing the study programs' curriculum is the most important part of the curriculum reform. Wina (2007). Similar treatment should be given in KKNI curriculum implementation. It is actually hoped that all lecturers, stakeholders and study programs association in Indonesia could hand in hand in developing KKNI based curriculum.

Some information about the lecturers' involvement in developing KKNI based curriculum at UIN Jakarta had been collected. And the result indicated that 17 study programs at UIN Jakarta had already involved their lecturers in developing KKNI curriculum by inviting the lecturers at several seminars, workshop, lecturers meeting and socialization which were held by the study programs, the faculty and the University.

Most of the KKNI socialization workshop had been held at 2013 in order to facilitate the lecturers to co mprehend and implement the new KKNI curriculum. Almost all of the 17 study programs revealed that they had conducted the workshop twice for the minimum.

\section{KKNI based curricculum documents readiness analysis}

Several documents dealing with KKNI curriculum implementations had been collected and analyzed in this study. The documents were vision, mision, profile, learning achievement, and semester teaching and learning activities plan. All those data were then analysed by document analysis instruments scale 1-3.

Due to the condition where the ordinal data is the data that should be analized, Likert scale was applied in this study. Score 1 was given for improper documents, score 2 was given for half proper documents and score 3 was given for proper documents. The application of Likert scale in this study is intended to provide in depth data analysis.

The data indicated that $96 \%$ of the study programs at UIN Jakarta has developed KKNI based currilum documents while $4 \%$ of the study programs in this university has not properly developed KKNI based curriculum documents. The diagram below illustrated this condition.

Diagram 2. The Result of Analysing Document of KKNI COURSE

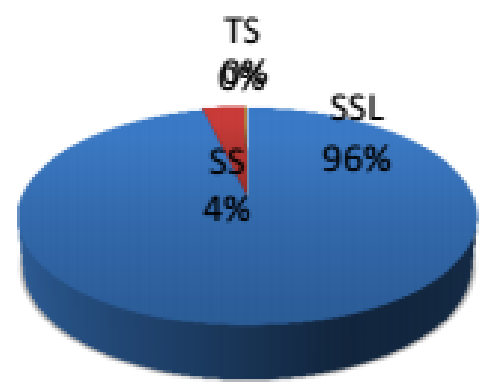

The next section of this article will present detail analysis research result about the KKNI based curriculum documents in several program studies at UIN Jakarta.

\section{The Development of Vision and Mission}

As explained in Presidential Decree No. 8 in 2012 that academic education, profession, or vocation for each stratum on one field of study is managed by the study program itself. The study program is in charge of designing, conducting, and evaluating the course curriculumso that the curriculum meets the relevance and quality aspects. In this case, the aspect of relevance include the user's needs, the elaboration of programs and strata understanding, and equality on KKNI based leveling competencies.

Through several analys on the readiness of the study programs in implementing KKNI based curriculum, it can be concluded that $99 \%$ of the 17 study programs which spread on 11 faculties have already developed a very proper and effective visions and misions. 
Diagram 3. Departments' vision and mission

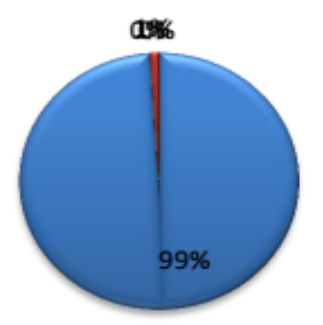

口SSL

The diagram above illustrated that $99 \%$ of study programs have developed vision and mission for the development of courses at UIN Jakarta and holistically suitable, and only $1 \%$ illustrates the unsuitability of direction at some aspects. The most important aspects in developing this vision and mision is relevancy so that when the mission can be formed it means that the vision can be achieved.

Based on the research results, it was also noted that the vision and mission created by the study programs had not stated the deadline when should the vision and mission of a study program achieved. This

\section{The Development of Profile of Course Graduates}

The development of the alumny profile of a study programs generally should be based on the SWOT analysis and tracer study. KKNI based curriculum stated that bachelor degree graduates should have level 6 competencies, which is called the "analist level". This level should become a reference in designing the alumny profile of a study program. Thus, the process of designing this alumny profile will affect the semester teaching and learning activities planning which cover some aspects such as attitudes, science, field of work, managerial, and responsibility.

The document analysis of the alumny profile revealed some information which were presented in the diagram below:
Diagram 4. The Development of Course Profile

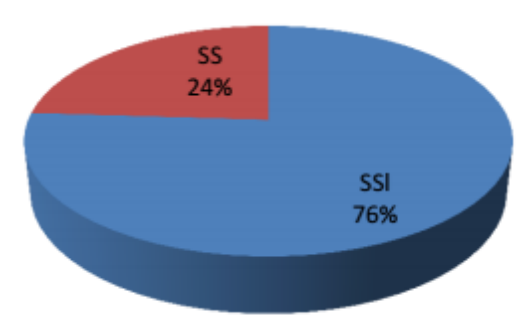

The diagram explained that $76 \%$ of the study programs have developed a proper alumny profile and the rest $24 \%$ of the study programs have developed an improper alumny profile. Almost all of those $24 \%$ of the study programs have over expanded their alumny profile by mentioning that their bachelor degree graduates could become a lecturer at the university.

"Teachers are required to have academic qualifications, competence, teaching certificate, physically and mentally healthy, and have the ability to realize the goals of national education (Article 8). That is same with the concept of Kunandar (2007) and Mulyasa (2002). Academic qualifications as referred to Article 8 that obtained through a higher education degree program or four diploma program" (Article 9).

Meanwhile, Indonesian rules of law stated that one needs to have Masters Degree or Stratum 2 to become a true high-qualified lecturer in a university. Law No. 14 of 2015 Article 45 and 46 about lecturers' qualification Lecturer stated that:

Lecturers are required to have academic qualifications, competence, teaching certificate, physical and mental health, and meet other qualifications which are required by higher education unit, and have the ability to realize the goals of national education (Article 45). (1) The academic qualifications of lecturers as referred to Article 45 should be acquired through accreditedhigher education graduate programs fit 
to areas of expertise. (2) Lecturers have a minimum academic qualification:

a. Graduates of the master degree program for diploma or bachelor degree program;

b. Graduates of doctoral programs for postdegree programs (Article 46).

\section{Courses' Learning Outcome}

Learning outcome of a study program should intercorrelate with the graduates competencies which is intended to be achieved. KKNI based curriculum mentioned that the learning outcomes should cover (1) attitude(s), (2) field of work ability, (3) knowledge, and (4) managerial and responsibility. Hasan Langgulung in Nasution stated that all of those four aspectsin the curriculum context associated with a number of educational experience, cultural, social, sports, and art both inside and outside the classroom that are managed by the school (Nasution, 1991: 9).

Learning outcome is one component that cannot be abandoned as what has been said in Law No. 20 of 2003 on National Education System in Article 1 (19) "Curriculum is a set of plans and arrangements regarding the objectives, content and learning materials as well as the means used to guide the implementation of learning activities to achieve specific educational objectives."Thus, it can be concluded that learning outcome should include several competencies developed to achieve educational goals. It is also described in Permendikbud No. 492014 that the curriculum is a set of plans and arrangements regarding learning outcomes of graduates, study materials, and assessment processes that are used as guidelines for the implementation of the program of study.

For this reason, KKNI based curriculum should also consist of learning outcomes. KKNI based learning outcomes should cover 1) the formulation of general attitudes, 2) general knowledge, primary and special knowledge, 3). General skills, both primary and special skills as has been stated at Presidential Decree No. 8 of 2012 about the National standard of Higher Education (SNPT) which is formed by program study association and the Indonesian government.

Based on the ideal concept of learning outcomes above, then it used to photograph the learning outcomes that have been developed by the study program in UIN Jakarta and the results are illustrated in the following diagram:

\section{Diagram5.The Development of Course Learning Outcomes}

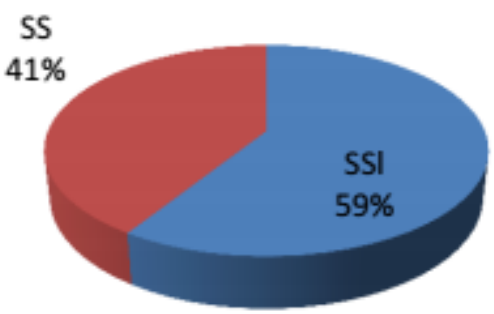

The diagram above illustrated that $59 \%$ of courses has developed the achievements of learning outcomeswhich are relevant to the development of vision, and a graduate profile, and contains the formula that should be included in the development of learning outcomes according to legislation which refers to Presidential Decree No. 8 of 2012 on the Indonesian National Qualifications Framework (KKNI) and Permendikbud number 49 of 2014 on National Education Standards of Higher Education (SNPT) that are formulated with the association of study programs, or based on the determination of Higher Education. The learning outcomes shouldbecomes a reference of capabilities of various study programsthat are needed in national, university, faculty, and courses level that includes 1) the formulation of general attitudes, 2) general, primary, and specialknowledge, and 3) the general, main and special skills. 
Meanwhile, there are $41 \%$ of courses at UIN Jakarta that develop unstandard learning outcomes because there is a mismatch of learning outcomes with the development of program of study in the graduate profiles. For example, the course stated that one of its graduate profiles is to become a lecturer but the learning outcomes of that course didnot depict any attempt to achieve this graduate profile.

\section{Structure of the course curriculum}

In line with the concept of a curriculum that requires the presence of a number of subject matter, the readiness of KKNI implementation is also cannot separated from the availability of curriculum structure. Sudjana (1991) described that the curriculum in education is defined as a number of subjects to be taken / completed by students to obtain a diploma. Similar to Sudjana's opinion, Martinis (2006) explains that the curriculum also called the process of teaching contents consist of a number of subjects which were arranged in a systematic and consistent with the things that are required as a condition to complete a process of specific educational activities. In this sense, curriculum defined as a design of subjects for a certain education level activity in which by masteringthat, someone can be declared as a graduate and has the right to obtain a diploma.

Therefore, the search-related data associated with the curriculum structure is directed to see a list of the subjects that are developed based on thematerial study and learning outcomes that have been formulated through a mechanism developed by each program of study at UIN Jakarta. Based on the study of the structure of the curriculum,it can be explained by the following diagram:
Diagram 6. The development of Curriculum KKNI

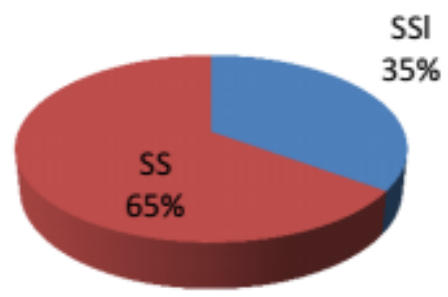

This diagram explains that the program of study in UIN Jakartadevelops the curriculum structure which becomes the basis of teaching as it is believed also by Crow and Crow and was quoted by Kaber (1998) that the curriculum is the design of teaching contents with number of subjects that were arranged systematically in and required as a condition for completing a particular educational program. But whether the completeness of the curriculum structure based on Indonesian National Qualifications Framework? The figure explains that $35 \%$ of study program has developed a curriculum based on KKNI structure which means that the development of the structure of the curriculum on the course in UIN Jakarta's environment hasa relevance to the development of vision, profile and learning outcomes that have been formulated before the materials study and curriculum structure was developed. In contrast, $65 \%$ of courses at UIN Jakarta developed irrelevant curriculum structure because they were not relevant to thecourse graduates profile and learning outcomes of study programs.

\section{Plan Class Semester courses}

Semester Lesson Plan (RPS) is a plan for the course in the outline that will be done during one semester. RPS is an integral part of the curriculum, which are prepared according to the guidelines of curriculum implementation. The completeness of the RPS has been developed by the study program was illustrated in the following diagram: 
Diagram 8. Study Program KKNI RPS

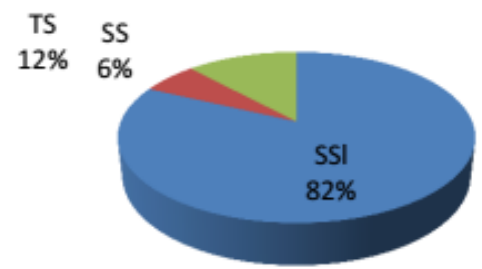

The diagram illustrated that $82 \%$ of courses at UIN Jakarta have developed Semester Lesson Plan (RPS) as a whole based on the applicable law underlying the formulation of RPS, that is Permendikbud No. 49 year 2014. Meanwhile, there are $6 \%$ of courses in UIN Jakarta that has developed Semester Lesson Plan, but there are still some components in the plan which is not complete yet. This means that there are some components that are not listed in the RPS. Besides, there are several terms used by the study program at UIN Jakarta to describe the planning of teaching and learning activities. The term GBPP is used by the Faculty of Medicine, RPS is used by the Faculty of Tarbiyah, Saintek, Dakwah, Psychology, and Dirasat Islamiyah), Syllabus is used by Faculty Ushuludin, and Sharia) Besides, there are $12 \%$ of courses at UIN Jakarta who have notdeveloped RPS since this data is collected, meaning that the course syllabus is still using the formula of syllabus and SAP prevailing in the 2014 curriculum, which is known as Unit Level curriculum (SBC).

Permendikbud No. 49 of 2014 on article 12, paragraph 3 stated that RPS should at least contain:

a) Name of the course, name and code of the courses, semester, credits, and lecturer'sname.

b) Learning outcomeswhich are charged to the course graduates.

c) The capabilities planned in each stage of learning to meet the learning outcomes of graduates

d) Learning Materials which are related to the skills that want to be achieved e) Learning methods

f) The time provided to achieve the ability of each phase of learning

g) The learning experience of students which are stated in the description of work that must be done by students for one semester

h) Criteria, indicators and weight assessment, and

i) List of used references.

\section{Conclusion}

Based on the research results that had been analyzed, it can be concluded that the readiness of study program atUIN Jakarta in the KKNI implementation can be declared as ready. This was proven in the course curriculum documents at UIN Jakarta in where $71 \%$ of study programs have sufficient KKNI-based course curriculum documents consisting of the vision, mission, and graduates profile, learning outcomes, curriculum structure and Semester Lesson Plan (RPS).

Besides, the readiness of courses in KKNI based curriculum can be evidenced by the quality of the documents that 1) $99 \%$ of study programs have developed a vision and mission for the implementation of the curriculum. 2) $77 \%$ of study programs have developed a profile of graduates according to level 6 that becomes the foothold of profile development for the undergraduate level. 3)59\% of study programs have formulated some learning achievements that in line with the learning outcomes defined for undergraduate level, level 6. 4) $35 \%$ of the structure of the course curriculum have met standard of KKNI implementation. 5) $82 \%$ of RPS of a study program has met the principles of expected RPS development in the KKNI implementation. Other evidence of the readiness of the implementation of the study program curriculum at UIN Jakarta is the involvement of lecturers in several workshops, seminars, socialization, and meetings and even the 
involvement of stakeholders to develop a course curriculum.

\section{References}

Achasius, K. (1988). Pengembangan Kurikulum. Jakarta: Depdikbud Dirjen Dikti Proyek Pengembangan LPTK.

Alwasilah, A. C. (2011). Pokoknya Kualitatif; Dasar-Dasar Merancang dan Melakukan Penelitian Kualitatif. Jakarta: PT. Dunia Pustaka.

Daryanto. (2005). Evaluasi Pendidikan. Jakarta: Rineka Cipta.

Hasan, H. (2005). Evaluasi Kurikulum. Bandung: Rosda Karya.

Hermawan, A. H. et. al. (2009). Kurikulum dan Pembelajaran. Bandung: Jurusan Kurikulum dan Teknologi Pendidikan Fakultas Ilmu Pendidikan Universitas Pendidikan Indonesia.

Idi, A. (2007). Pengembangan Kurikulum; Teori dan Praktik. Yogyakarta: Ar-Ruzz Mediacet. 2.

Kunandar. (2007). Guru Profesional; Implementasi Kurikulum Tingkat Satuan Pendidikan (KTSP). Jakarta: PT. Rajagrafindo Persada.
Moleong, L. (2007). Metodologi Penelitian Kualitatif. Bandung: Remajarosdakarya

Muhaimin. (2007). Pengembangan Kurikulum Pendidikan Agama Islam di Sekolah, Madrasah dan PerguruanTinggi. Jakarta: PT RajagrafindoPersada.

Mulyasa, E. (2002). Manajemen Berbasis Sekolah; Konsep, Strategi, dan Implementasinya. Bandung: Remaja Rosdakarya.

Nasution, S. (1982). Asas-Asas Kurikulum. Bandung: Jemmars.

Sudjana. (1991). Metode Penelitian Kualitatif. Jakarta: PT. Grasindo.

Sanjaya, W. (2007). Kurikulum dan Pembelajaran: Teori dan Praktik KTSP. Jakarta: Prenada Media.

Sukmadinata, N., S. (2011). Pengembangan Kurikulum: Teori dan Praktek. Bandung: PT. Remaja Rosdakarya.

Yamin, M. (2006). Profesionalisasi Guru \& Implementasi Kurikulum Berbasis Kompetensi. Jakarta: Gaung Persada Press. 